\title{
STUDYING HISTOPATHOLOGICAL CHANGES IN SUPRARENAL GLAND VERSUS VITREOUS HUMOR POTASSIUM LEVEL IN ESTIMATION OF POSTMORTEM INTERVALS: EXPERIMENTAL STUDY IN RABBITS
}

\author{
Soheir A. Mohamed ${ }_{1}$, Rania A. Radwan ${ }_{1}$, Afaf T. Elnashar 2 , Eman Salama 3 , Shams \\ M.Adel 1 \\ 1Forensic Medicine and Clinical Toxicology Department \\ 2Pathology Department \\ 3 Clinical Pathology Department \\ Faculty of Medicine, Sohag University.Sohag, Egypt
}

\begin{abstract}
Corresponding Author: Shams M. Adel
E-mail:drshams.Hamada@yahoo.com.

Postal address: Department of Forensic Medicine and Clinical Toxicology, Faculty of Medicine, Sohag University, Nasr city, Sohag, Egypt.
\end{abstract}

\begin{abstract}
Background: Estimation of post-mortem intervals (PMI) is a critical step in most unwitnessed death investigations. After death, bodies begin to decompose in regular patterns which are used to estimate physiological time of death. These changes occur in widely variable ways and no single factor accurately indicates PMI. Objectives: This work aimed to compare between two different methods in estimation postmortem interval which are histopathological changes in suprarenal gland and vitreous humor potassium level. Materials and methods: The study was conducted on 50 Newzeland male rabbits, at the beginning of the study the rabbits were sacrificed by cervical dislocation then they were classified into 5 groups (I, II, III, IV, V) according to the PMI (0, 6., 12., 18 and 24 hours ) respectively. Histopathological and histometric examination [chromaffin cell count (cell $/ 100 \mu^{2}$ ), medullary surface area $\left(\mu \mathrm{m}^{2}\right)$ and total chromaffin cell count] for left suprarenal were done. Spectroscopic determination of vitreous humor potassium was done. Results: There was significant statistical increase in the mean value of chromaffin cell count (cell/um ${ }^{2}$ ) and the vitreous humor potassium level $(\mathrm{mEq} / \mathrm{L})$ with increased PMI (P-value was 0.001$)$. On contrast, there was significant statistical decrease in the mean value of the suprarenal medullary area $\left(\mu \mathrm{m}^{2}\right)$ and total chromaffin cell count with increased PMI (P-value was 0.001). The results showed significant positive correlation between the vitreous humor potassium level $(\mathrm{mEq} / \mathrm{L})$ and chromaffin cell count $\left(\right.$ cell $\left./ 100 \mu \mathrm{m}^{2}\right)$. On the other hand the findings showed significant negative correlation between the vitreous humor potassium level

$(\mathrm{mEq} / \mathrm{L})$ and the suprarenal medullary area $\left(\mu \mathrm{m}^{2}\right)$ and total chromaffin cell (P value was 0.001). Conclusion: The vitreous humor potassium level in combination with the chromaffin cell count $\left(\right.$ cell $\left./ 100 \mu \mathrm{m}^{2}\right)$, suprarenal medullary area and total chromaffin cell count can give more accurate estimation of the postmortem intervals.
\end{abstract}

Keywords: postmortem interval, suprarenal gland, vitreous humor potassium. 


\section{INTRODUCTION}

An accurate determination of PMI is useful in solving many civil matters such as identification of unknown dead persons and inheritance (Mathur and Agrawal, 2011). After death, bodies begin to decompose in regular patterns which are used to estimate physiological time of death. There is no single factor accurately indicates PMI (Lyle, 2004).

Many researches have been carried out as regard the relationship between the postmortem interval and decomposition of organs such as the heart, sublingual salivary gland. Although, the suprarenal gland is one of the tissues that undergoes autolysis early in the human body its postmortem interval studies are lacking (Kurtulus et al., 2012).

Vitreous Humor (VH) is preferred for post-mortem investigations because it has a stable composition and minimally affected by rapid changes in the blood composition (Garg et al., 2004). Vitreous humor potassium content is the most used chemical indicator before putrefaction (Coe, 1993).

Comparing two different methods to estimate PM intervals can give more accurate results so, the present study used both vitreous humor potassium level and histopathological changes affecting the suprarenal gland to estimate the PM intervals

\section{MATERIAL AND METHODS}

\section{1- Animals:}

Ethics and husbandry conditions for animal research were approved from Sohag Faculty of Medicine Ethical Committee. The animals were kept and housed in animal house, Faculty of Medicine, Sohag University, Egypt, with room temperature being maintained $(20 \pm 2$ $\left.{ }^{\circ} \mathrm{C}\right)$. The study was conducted on 50 Newzeland male rabbits weighting about 2.5-3.5 Kg obtained from the animal house at the faculty of agriculture, Sohag University, Egypt. At the beginning of the study the rabbits were sacrificed by cervical dislocation under anesthesia, then they were classified into 5 groups ten rabbits each (I, II, III, IV, V) according to the PMI (0, 6., 12., 18 and 24 hours ) respectively. They were kept in protective cages with plastic on the floor and kept at temperature $22^{\circ} \mathrm{Cand} 50 \%$ humidity for different postmortem interval.

\section{2- Chemicals and Reagents}

Hematoxyline and Eosin stains were purchased from ALPHACHEMIKA, 10\% formalin, paraffin. Spectrophotometric kit for detection of potassium level manufactured by Randox, North Irland.

\section{3- Instruments:}

Dissection tools, plastic syringe $3 \mathrm{~cm}$ and $20 \mathrm{~cm}$, propylene tubes, Leica RM2125RT microtome, Olympus CX 41 RF Light field microscopy and camera connected to a light microscope (computer Olympus digital camera E-330) at the Sohag histopathology department, China. Spectrophotometer 5010 at Sohag Clinical Pathology Laboratory, China.

\section{4-Collection of samples:}

The vitreous humor was gently aspirated from posterior chamber of the left eye (Kurtulus et al, 2012) using a $20 \mathrm{~cm}$ syringe. Each was collected and put in tube made of polypropyle and was kept at $18^{\circ} \mathrm{C}$ for later evaluation using the spectrophotometer. The left suprarenal gland was excised rapidly and placed in $10 \%$ formalin solution. The specimens were processed and then embedded in paraffin. From each gland five sections (each $30 \mu \mathrm{m}$ thick) were taken by the microtome. The specimens were stained by Hematoxylin and Eosin. Then histopathological examination was done using Olympus CX 41 RF microscope and histometric examination was done using the same microscope connected to a computer through Olympus digital Camera 
E-330. Photomicrographs were obtained and processed using cell $\wedge \mathrm{B}$ software for histopathological changes affecting the suprarenal gland. Estimation of chromaffin cell count (cell $/ 100 \mu \mathrm{m}^{2}$ ) (X400) was done in five different fields for each section (five reading $\mathrm{X}$ five sections for each animal). The boundary of the medulla was demarcated and a medullary surface area $\left(\mu \mathrm{m}^{2}\right)$ (X100) was estimated for each section (five for each animal). Total chromaffin cell count were calculated by multiplying chromaffin cell count (cell $\left./ 100 \mu \mathrm{m}^{2}\right)$ by medullary surface area $\left(\mu \mathrm{m}^{2}\right)$ then divided by 100 . Total chromaffin cell count was calculated by calculating five reading $\mathrm{X}$ five sections for each animal. The mean reading for each animal was calculated. All statistical procedures were computed using the Statistical Program for Social Science (SPSS), version 16.0 computer software. SPSS Inc. Chicago, USA. All data were presented as mean \pm S.D and they were calculated by ANOVA. Significance was considered at $\mathrm{p}$-value less than $0.05 \%$.

\section{RESULTS}

There was significant statistical increase in the mean value of PM potassium level in the vitreous humor $(\mathrm{mmol} / \mathrm{L})(\mathrm{P}<0.01)$ table $(1)$.

Table (1): The mean value of PM potassium level in the vitreous humor at different postmortem intervals.

\begin{tabular}{|l|c|c|c|c|c|c|}
\hline \multirow{2}{*}{ Groups } & I & II & III & IV & V & \multirow{2}{*}{ P-Value } \\
\cline { 2 - 6 } Parameters & Mean \pm SD & Mean \pm SD & Mean \pm SD & Mean \pm SD & Mean \pm SD & \\
\hline $\begin{array}{l}\text { Potassium level } \\
(\mathrm{mmol} / \mathrm{L})\end{array}$ & $4.5 \pm 0.33$ & $7.2 \pm 0.34$ & $9.6 \pm 0.35$ & $12.2 \pm 0.65$ & $16.6 \pm 0.53$ & $0.001 *$ \\
\hline
\end{tabular}

* Significant $\mathrm{P}$ value.

SD: Standard deviation

Histopathological changes in suprarenal gland at 0 hours (group I) showed normal histological structure with well recognized cortex and medulla. The three zones of the cortex were normal in structure and architcture. Zona granulosa (ZG) epithelial cells were normal with intact basement membrane and had hyperchromatic nuclei. The sinusoids in the zona fasciculata (ZF) and zona reticularis $(\mathrm{ZR})$ were normal, non dilated and showed normal endothelial cells. The cytoplasm of most cells was normal, abundant and hyperchromatic. Medulla (M) was well recognized from cortex with completely hyperchromatic nuclei and normal preserved blood vessels. At 6 hours postmortem (group II), there was no significant change in the suprarenal architecture. While at 12 hours (group III) cells of $\mathrm{ZG}, \mathrm{ZF}$ and $\mathrm{ZR}$ were welldifferentiated, showed some vacuoles in the cytoplasm and pyknosis of some nuclei. There was some dilatation of the sinusoids with some prominence of their endothelial cells. There was indistinct 
cellular outline of the medulla. At 18 hours postmortem (group IV) and 24 hours postmortem (group V), the three zones of the cortex cannot be differentiated. The cellular outlines of the $\mathrm{ZG}, \mathrm{ZF}$ and $\mathrm{ZR}$ and of the suprarenal medulla were completely absent and the nuclei were totally pyknotic with vacuolation of the cytoplasm.
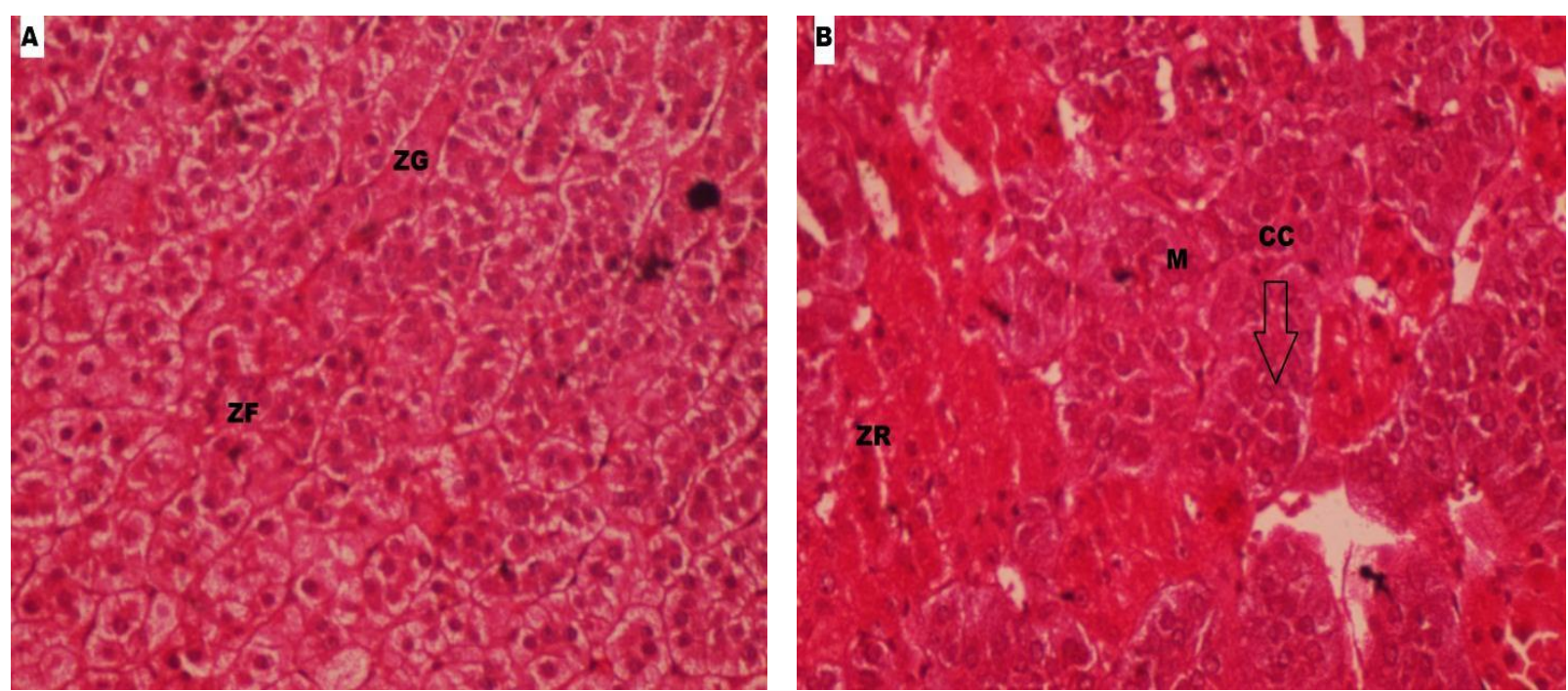

Figure (1 A\&B): A photomicrogragh of a section in suprarenal gland of group I (at 0 hours). It shows normal architecture with well differentiated cortex and medulla. The cortex shows normal histological structure of the three zones, zona glomerulosa (ZG), zona fasciculata (ZF), zona reticularis (ZR) and of the chromaffin cell (CC). (Hx\&E stain, 400x).
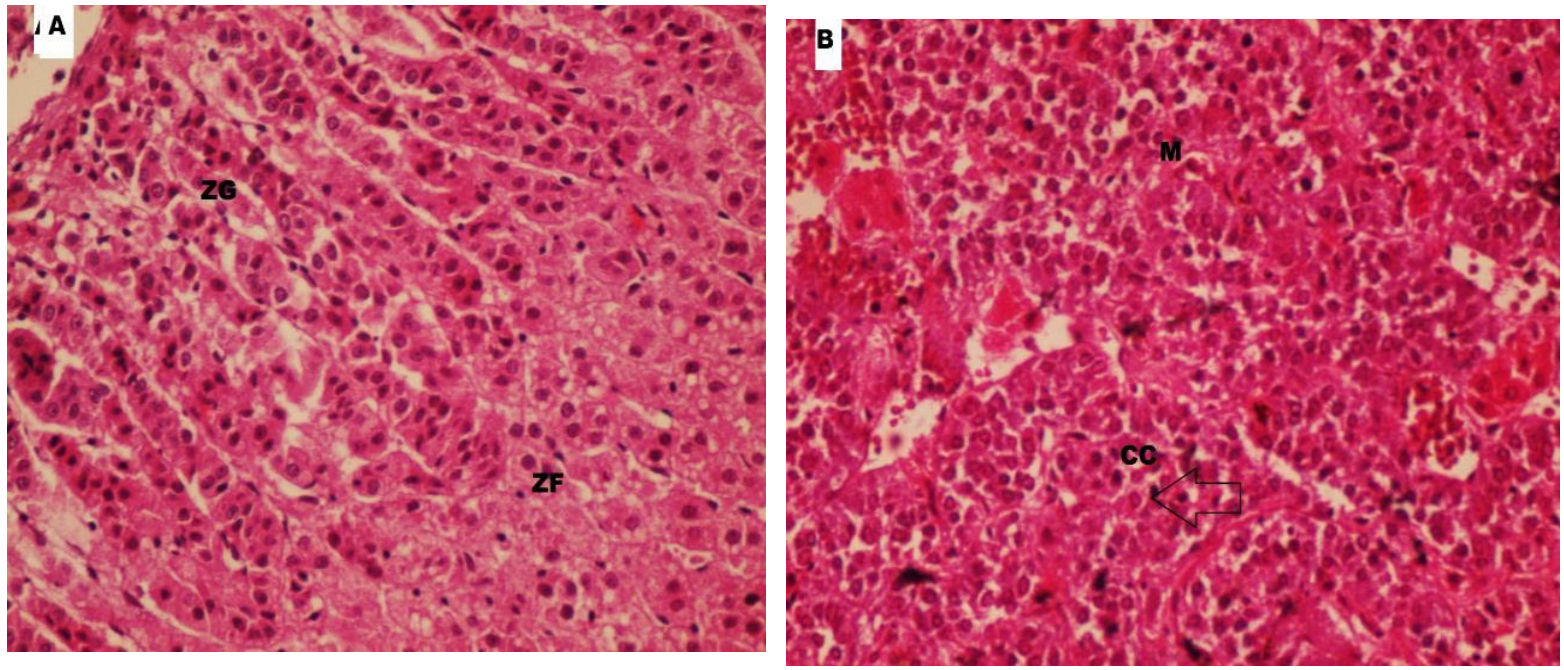

Figure (2 A\&B): A photomicrogragh of a section in suprarenal gland of group II (at 6 hours). It shows normal maintained architecture with well differentiated cortex and medulla, hyperchromatic and eosinophilic abundant cytoplasm. Medulla (M) was distinct and well differentiated from cortex; most of the nuclei were completely hyper chromatic with normal intact blood vessels.

(Hx\&E stain, 400x). 

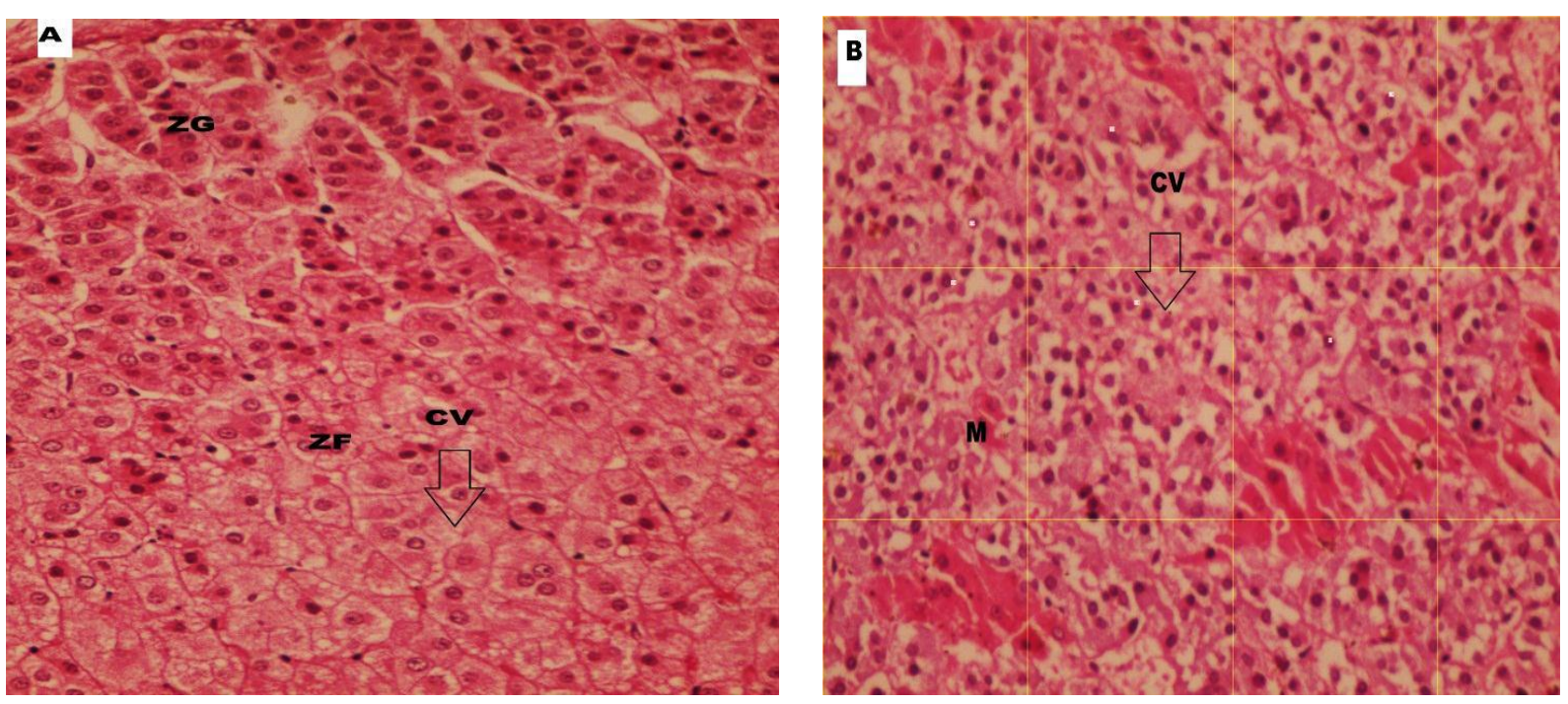

Figure (3 A\&B): A photomicrogragh of a section in suprarenal gland of group III (at 12 hours). It shows cytoplasmic vacuolation $(\mathrm{CV})$ in the cell layers of the suprarenal cortex zona glomerulosa (ZG) \& zona fasciculata (ZF) and the chromaffin cells of the suprarenal medulla (M).
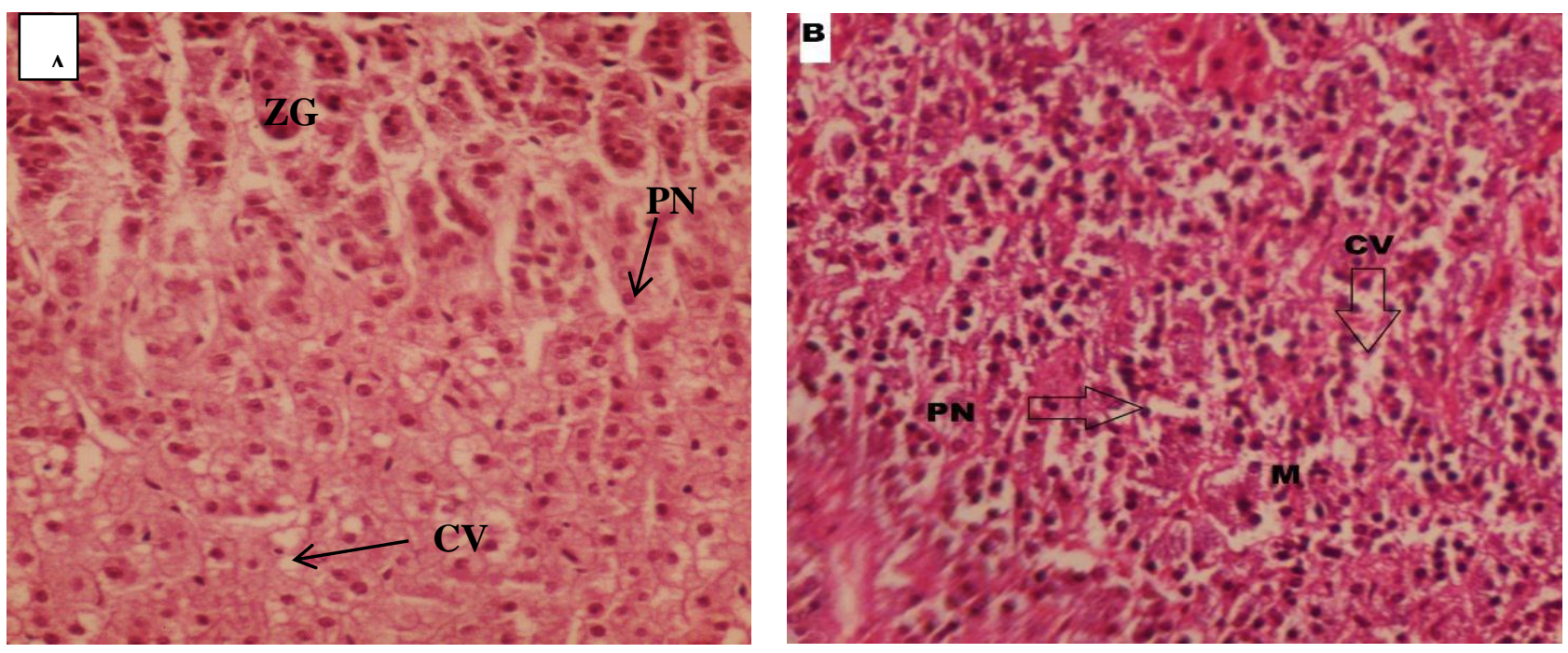

Figure (4 A\&B): A photomicrogragh of a section in suprarenal gland of group VI (at 18 hours). It shows marked cytoplasmic vacuolation (CV) and nucleic pyknosis (PN) in all layers of the suprarenal cortex and medulla $(\mathrm{M})$.

(Hx\&E stain, 400x). 

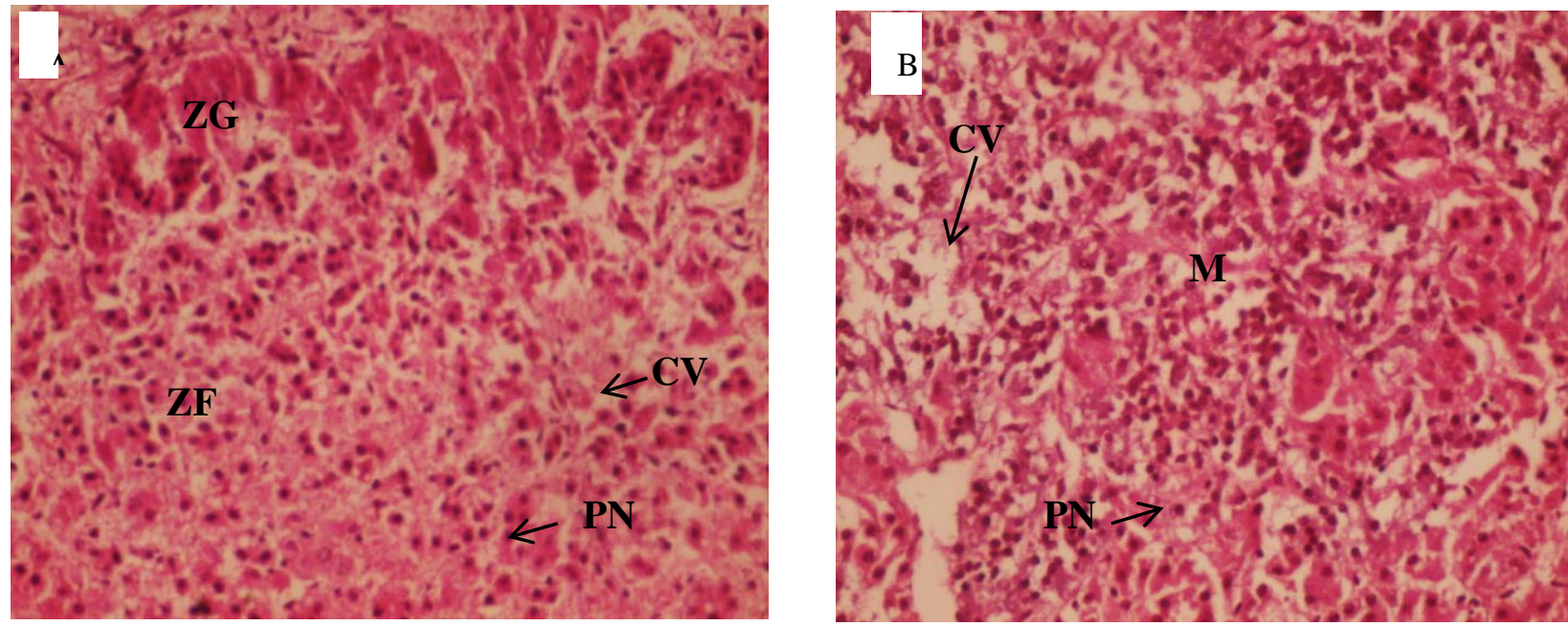

Figure (5 A\&B): A photomicrogragh of a section in suprarenal gland of group $V$ (at 24 hours). Fig (A): It shows the different layers of the suprarenal cortex where they cannot be distinguished from each other. The nuclei are markedly pyknotic (PN). Fig (B): The medullary nuclei are markedly pyknotic.

(Hx\&E stain, 400x).

Histometric examination showed that there was significant statistical increase in the mean value of the Chromaffin cell count in the suprarenal medulla (cell $/ 100 \mu \mathrm{m}^{2}$ ) in different rabbit's groups (I, II, III, IV and V) $(\mathrm{P}<0.05)$ table (2). There was significant statistical decrease in the mean value of the suprarenal medullary area $\left(\mu \mathrm{m}^{2}\right)$ in different rabbit's groups (I, II, III,
IV and V) $(\mathrm{P}<0.01)$ table (2).There was significant statistical decrease in the mean value of the total postmortem chromaffin cell count in the suprarenal medulla in different rabbit's groups (I, II, III, IV and V) $(\mathrm{P}<0.01)$ table $(2)$. 
Table (2): The mean value of chromaffin cell count $\left(\right.$ cells $\left./ 100 \mu \mathrm{m}^{2}\right)$, area of suprarenal medulla $\left(\mu \mathrm{m}^{2}\right)$ and total chromaffin cell count at different postmortem intervals.

\begin{tabular}{|c|c|c|c|c|c|c|}
\hline \multirow{2}{*}{ Groups } & I & II & III & IV & $\mathbf{V}$ & \multirow[b]{2}{*}{ P-Value } \\
\hline & $\begin{array}{l}\text { Mean } \\
\pm \text { SD }\end{array}$ & $\begin{array}{l}\text { Mean } \\
\pm \text { SD }\end{array}$ & $\begin{array}{l}\text { Mean } \\
\pm \text { SD }\end{array}$ & $\begin{array}{l}\text { Mean } \\
\pm \text { SD }\end{array}$ & $\begin{array}{l}\text { Mean } \\
\pm \text { SD }\end{array}$ & \\
\hline $\begin{array}{l}\text { Chromaffin cell } \\
\text { count }\left(\text { cell } / 100 \mu \mathrm{m}^{2}\right)\end{array}$ & $\begin{array}{r}35 \\
+1.26\end{array}$ & $\begin{array}{c}40.4 \\
\pm 0.23\end{array}$ & $\begin{array}{r}48 \\
+0.25\end{array}$ & $\begin{array}{r}57.6 \\
\pm 0.26\end{array}$ & $\begin{array}{r}78.1 \\
\pm 0.12\end{array}$ & $0.001 *$ \\
\hline $\begin{array}{l}\text { Medullary Area } \\
\qquad\left(\mu \mathbf{m}^{2}\right)\end{array}$ & $\begin{array}{r}12570 \\
\pm 38.53\end{array}$ & $\begin{array}{r}10440 \\
\pm 92.62\end{array}$ & $\begin{array}{c}7250 \\
\pm \mathbf{5 0 . 8 4}\end{array}$ & $\begin{array}{r}4280 \\
\pm 58.1\end{array}$ & $\begin{array}{c}2206 \\
\pm 93.14\end{array}$ & $0.001 *$ \\
\hline $\begin{array}{c}\text { Total Chromaffin } \\
\text { cell }\end{array}$ & $\begin{array}{r}4382.6 \\
\pm 38.83\end{array}$ & $\begin{array}{r}4068.6 \\
\pm 34.53\end{array}$ & $\begin{array}{r}3479.3 \\
\pm 35.94\end{array}$ & $\begin{array}{r}2486.2 \\
\pm 30.88\end{array}$ & $\begin{array}{c}1696.7 \pm \\
16.29\end{array}$ & $0.001 *$ \\
\hline
\end{tabular}

* Significant $\mathrm{P}$ value.

SD: Standard deviation

The results of the present work showed significant positive correlation between the vitreous humor potassium level $(\mathrm{mEq} / \mathrm{L})$

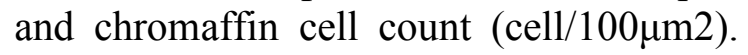
On the other hand the findings showed significant negative correlation between the vitreous humor potassium level

Table (3): Correlation between PM potassium level in the vitreous humor (mmol/L) and the histometric parameters of the suprarenal gland.

\begin{tabular}{|c|c|c|}
\hline Parameters & $\begin{array}{c}\text { Correlation co- } \\
\text { efficient }\end{array}$ & P-value \\
\hline $\begin{array}{c}\text { Chromaffin cell } \\
\text { count }(\text { cell/ } \mu \mathrm{mm})\end{array}$ & $\mathbf{0 . 9 7 9}$ & $\mathbf{0 . 0 0 1 *}$ \\
\hline $\begin{array}{c}\text { Suprarenal } \\
\text { medullary area } \\
(\mu \mathrm{\mu m})\end{array}$ & $-\mathbf{0 . 9 8 8}$ & $\mathbf{0 . 0 0 1 *}$ \\
\hline $\begin{array}{c}\text { Total chromaffin } \\
\text { cell count }\end{array}$ & $-\mathbf{0 . 9 7 4}$ & $\mathbf{0 . 0 0 1 *}$ \\
\hline
\end{tabular}

*Significant correlation 


\section{DISSCUSION}

Estimation of postmortem interval is very important for many forensic cases. The extent of autolysis is an important factor that has been used in determining the time passed since death. Decomposition occurs in two processes, autolysis and putrefaction (Dogan et al., 2010). Autolysis affects organs at different rates according to the composition and structure of that organ where, organs with the high content of lytic enzymes almost always decompose first, as the suprarenal glands (Cocariu et al., 2016). There are many nuclear alterations that occur progressively such as karyorrhexis, karyolysis and pyknosis followed by complete disappearance of the nucleus. Finally the cytoplasm turns to an acidophilic and granular opaque mass (Kurtulus, 2012).

The analysis of the body fluids taken after death biochemically provide important data regarding the underlying cause of death and PMI estimations (Donaldson, 2014). Although after death respiration and circulation stop completely, the cellular metabolic activities continue in their tissues for different duration then, death of the cells occurs and metabolism becomes autolysis, ending in losing the selective membrane permeability. In different body compartments passive diffusion of ions occurs as the PMI progresses. During life, the vitreous humor potassium level is low while, it is higher in the peripheral tissues of the eye as choroid and retina (Swain et al., 2015).

As regard the $\mathrm{VH}$ potassium level, the results could be explained by vascular choroids and retinal cells of the eye humor decomposition after death $(\mathrm{mEq} / \mathrm{L})$ (Lie, 1967).

The present results were in agreement with Jaffe (1962) who reported significant increase in the PM potassium values in both aqueous and vitreous humors at 2 and 24 hours. Also, Coe, J.
(1969) who studied the usefulness of using $\mathrm{VH}$ potassium level in estimating PMI by calculating it in the vitreous humor of both eyes and there was marked increase in potassium concentration of the vitreous humor with increasing PMI.

Farmer et al. (1985) used the levels of different electrolytes as magnesium, potassium, sodium and calcium in humanitarian vitreous humor after death to evaluate its effectiveness in estimating PMI. They found that there was a positive correlation and marked increase of potassium level with the length of the postmortem interval. The results were also in agreement with Rajinderjit, et al. (2011) found marked increase in the potassium levels with progressing PMI. The authors added that it is an accurate method to determine PMI as environmental factors as humidity and the atmospheric temperature didn't affect the vitreous potassium level greatly. Bohra, et al. (2014) also found a linear relationship between the increase in vitreous potassium $\left(\mathrm{K}^{+}\right)$concentration and the increase in postmortem interval that was both arithmetic and as well as logarithmic.

In the present work, we noted an increase in the total size of the cells that has a linear relationship with intracytoplasmic vacuolar degenerative change. Then, there were nuclear degenerative changes, such as karyolysis, pyknosis and karyorrhexis. The first cellular damage is mostly cellular swelling, what is called "hydropic degenration".

These results were in agreement with Kurtulus, et al. (2012) who studied the postmortem changes affecting the adrenal gland at different postmortem intervals (0h, 12h, 24h) where, the adrenal gland, medullary cell nuclei pyknosis together with cytoplasmic vacuolization were noted. With progressing PMI cellular shrinkage, karyolysis and cell destruction occur.

Alejandro, and Strafuss, (1984) reported decreases in the size of the 
medullary cell nuclei with pyknosis, cytoplasmic vacuolization and eventually cellular decomposition due to autolysis (Cocariu et al., 2016).

As regard the chromaffin cell count

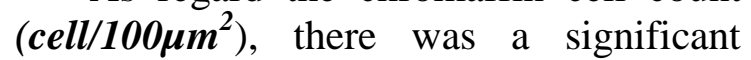
statistical increase in the mean value of the chromaffin cell count $\left(\mathbf{c e l l} / \mathbf{1 0 0} \boldsymbol{\mu m}^{2}\right)$, with increasing the time elapsed since death $(\boldsymbol{P}$ value $\mathbf{0 . 0 0 1}$ ). Also, there was significant positive correlation between the chromaffin cell count and the postmortem interval.

These results were explained by significant statistical decrease in the mean value of the suprarenal medullary area in different groups of rabbits with increasing the postmortem interval that was noted by significant negative correlation between the suprarenal medullary area and the postmortem interval.

The increase in the chromaffin cell count was only an apparent increase (as with increasing PMI there was significant statistical decrease in the suprarenal medullary area so the cells become crowded in narrow area so the number of the nuclei in the $100 \mu \mathrm{m}^{2}$ become increased) this was proved by the fact that there was a significant statistical decrease in the total number of the chromaffin cell in the total medullary area between different rabbit groups with the increase in PM interval.

These results were also in agreement with Elgawish, et al. (2016) who found that the medullallary volume significantly decreases $(\mathrm{P}=0.03)$ time passed after death increases.

\section{CONCLUSION}

From the obtained results, it was found that each of the vitreous humor potassium level; the chromaffin cell count and suprarenal medullary area could be used for estimation of the postmortem interval. Using of the vitreous humor potassium level in combination with either the chromaffin cell count or suprarenal medullary area, the total chromaffin cell count give more accurate estimation of the postmortem interval.

\section{RECOMMENDATIONS}

Studying postmortem suprarenal gland changes at more PMI and at different environmental conditions. Human studies for accurate equations of PMI. Comparing between the left and right suprarenal glands.

\section{REFERENCES}

Alejandro, V. and Strafuss, A. (1984): Microscopic postmortem changes in adrenal glands of the domestic fowl. Avian Dis., 28:374-385

Cocariu, E. A.; Mageriu, V.; Staniceanu, F.; Socoliuc, C.; Zurac, S. and Bastian A. (2016): Correlations between the autolytic changes and postmortem interval in refrigerated Cadavers. J. INTERN. MED., 54: 105-112.

Coe, J. (1969): Postmortem chemistries on human vitreous humor. Am J ClinicPathol. 51:741-750

Coe, J.I. (1993): Postmortem chemistry update. Emphasis on forensic application. Am J Forensic Med Path., 2:91-117.

Dogan, K.; Gunaydin, G.; Demirci, S. and Koc, S. (2010): Postmortem changes in element levels in rat skeletal muscle tissue. Turkiye Klinikleri J Med Sci., 30: 1332-1338.

Donaldson, A. E. and Lamont, I. L. (2014): Estimation of postmortem interval using biochemical biomarkers. Asturalian Journal of Forensic Sciences, 46: 8-26.

Elgawish, R. A.; Abdelrazek, H. M. and Ghanem, M. (2016): Postmortem changes in electrolytes and adrenal gland at different intervals in adult male rats. ARC Journal of Animal and 
Veterinary Sciences (AJAVS), 2: 1522

Farmer, J.; Benomran, F.; Watson, A. and Harland, W. (1985): Magnesium, potassium sodium and calcium in postmortem vitreous humor from humans. Forensic Sci Int; 27:113.

Garg, V.; Oberoi, S.; Gorea, R. and Kiranjeet, K.(2004): Changes in the levels of vitreous potassium with increasing time since death. JIAFM., 26: 136-139.

Jaffe F. (1962): Chemical postmortem changes in the intraocular fluid. JForensic Sci. 7:231-237.

Kurtulus, A.; Acar, K.; Sorkun, H.; Kelten, C. and Boz, B. (2012): The relationship between adrenal gland morphometric changes and postmortem interval in rats: A stereological study. J. Legal Med., 14: 214-218.

Lie, J.T. (1967): Changes of potassium concentration in vitreous humor after death. Am J Med Sci. 254:136-142.

Lyle, D.P. (2004): estimating the time of death. In: Forensic For Dummies Indiana, $1^{\text {st }}$ Ed., Wiley publishing Inc., PP: 161-173.

Mathur, Ak. and Agrawal, YK. (2011): An overview of methods used for estimation of time since death. Aust J. Forensic Sci., 43:275-285.

Nery, L. R.; Moreira, C. R.; Cestari, T. M.; Taga, R. and Damante, J. H. (2010): Post mortem acinar autolysis in rat subligual gland: a morphometric study. Journal of applied oral science, 18: $509-514$.

Swain, R.; Kumar, A.; Sahoo, J. R.; Lakshmy, S.; Gupta, D.; Bhardwaj, R. and Pandey (2015): Estimation of post-mortem interval: A comparison between cerebrospinal fluid and vitreous humor chemistry. Journal of Forensic and Legal Medicine, 36:144148.

Rajinderjit, S.A. and Vishal, G. (2011): Role of vitreous potassium level in estimating postmortem interval and the factors affecting it. Journal of clinical and diagnostic research 5:1315. 


\section{الملخص العربي}

دراسة التغيرات الهستوبولوجية في الغدة الكظريه و مستوى البوتاسيوم في السائل الزبحاجي للعين لتحديد الفتره الزمنيه بعديه الوفاة: دراسة تجريبية في الأرانب الزي لئدين سهير علي محمد، رانيا احمد رضوان، عفاف طه النشار، ايمان سلامة، شمس محمد عادل قسم الطب الثرعي و السموم الاكلينيكيه قسم الباثولوجيا الطبيه

قسم الباثولوجيا الاكلينيكيه كليه الطب البشري - جامعه سوهاج- جمهوريه مصر العربيه

\section{ملخص البحث}

مقدمة: يعتبر تقدير الفترات الزمنيه بعد الوفاة خطوة حاسمة في معظم تحقيقات الوفاة غير المعلوم زمن حدوثها. بعد الموت ، يبدأ تحلل الاجسام في أنماط منتظمة التي تستخدم في تقدير الوقت الفسيولوجي للوفاة. تحدث هذه التغييرات بطرق مختلفه على نطاق واسع وليس هناك عامل و احد يشير بدقة إلى هذه المده. هدف الدراسة: يهدف هذا العمل إلى المقارنة بين طريقتين مختلفتين في تقدير الفترات الزمنيه بعد الوفاة و هي التغيرات النسيجية في الغدة الكظريه ومستوى البوتاسيوم في السائل الزجاجي للعين. منهج الدراسة: تم اجر اء هذه الدراسه على •0 من الأرانب النيوزيلانديه الذكور ، في بداية الدراسة تم قتل جميع الأرانب

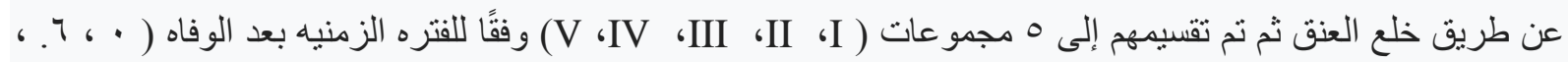

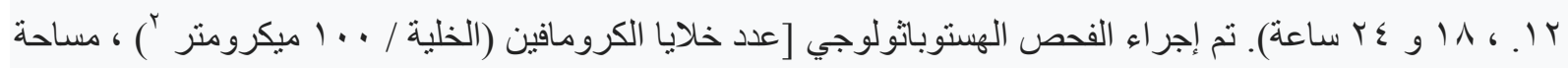
النخاع للغده (ميكرو r) و إجمالي عدد خلايا الكرومافين]. تم إجر اء التحليل الطيفي لتحديد مستوي البوتاسيوم في السائل الزجاجي للعين.

نتيجه البحث: كانت هنالك زيادة ذات دلاله احصائيه في متوسط عدد خلايا الكرومافين (الخلية / ميكرو؟ّ) ومستوى البوتاسيوم في السائل الزجاجي للعين (ملليمول/ لتر) مع زيادة الفتره الزمنيه بعد الوفاه. وعلى النقيض ، كان هناك انخفاض ذو دلاله إحصائية في منوسط مساحه النخاع للغده (ميكرو ؟) و إجمالي عدد خلايا الكرومافين مع زيادة الفتره الزمنيه بعد الوفاه. بالإشارة إلى الترابط ، أظهرت النتائج وجود ارتباط إيجابي بين مستوى البوتاسيوم في السائل الزجاجي للعين(ملليمول/

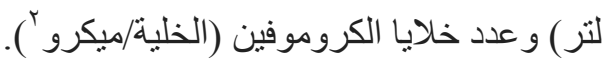


و من ناحية أخرى ، أظهرت النتائج ارتباطًا سلبيًا بين مستوى البوتاسيوم ف السائل الزجاجي للعين ( ملليمول /لتر) و

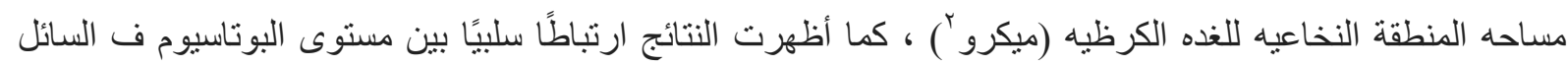
الزجاجي للعين ( ملليمول /لتر ) و العدد الكلي لخلايا الكرومافين.

نتيجه الدراسة: نستطيع تحديد الفترات الزمنيه بعد الوفاه بصوره اكثر دقه عن طريق استخدام مستوى البوتاسيوم في السائل الزجاجي للعين بالاقتران مع عدد خلايا الكرومافين (الخلية / . . (ميكرو ؟) ، ومساحه منطقة النخاع للغده الكظريه ، و العدد الكلي لخلايا الكرومافين. 